\title{
Fixed-Dose Combination of Tafluprost and Timolol in the Treatment of Open-Angle Glaucoma and Ocular Hypertension: Comparison with Other Fixed- Combination Products
}

Gábor Holló · Jouni Vuorinen · Juhani Tuominen •

Teppo Huttunen $\cdot$ Auli Ropo $\cdot$ Norbert Pfeiffer

To view enhanced content go to www.advancesintherapy.com

Received: July 31, 2014 / Published online: September 12, 2014

(c) The Author(s) 2014. This article is published with open access at Springerlink.com

\section{ABSTRACT}

A new preservative-free fixed-dose combination of $0.0015 \%$ tafluprost, a prostaglandin $\mathrm{F}_{2 \alpha}$ analog, and $0.5 \%$ timolol (TAF/TIM; Santen Oy, Tampere, Finland), a beta-adrenergic antagonist has recently been developed. The intraocular pressure (IOP) reduction with TAF/ TIM in open-angle glaucoma and ocular hypertension is similar to that of other

Electronic supplementary material The online version of this article (doi:10.1007/s12325-014-0151-7) contains supplementary material, which is available to authorized users.

G. Holló (ه)

Department of Ophthalmology, Semmelweis

University, Budapest, Hungary

e-mail: hgbudapest@gmail.com;

hollo.gabor@med.semmelweis-univ.hu

J. Vuorinen $\cdot$ T. Huttunen

Oy 4Pharma Ltd, Turku, Finland

J. Tuominen

Department of Mathematics and Statistics,

University of Turku, Turku, Finland

A. Ropo

Santen Oy, Clinical Research and Medical Affairs,

Helsinki, Finland

N. Pfeiffer

Department of Ophthalmology, Mainz University

Medical Center, Mainz, Germany prostaglandin-timolol fixed-combination products. Patients with high IOP responded well to TAF/TIM with reductions of up to $40 \%$ (>13 mmHg) and beyond. Compared to previous controlled and double-masked clinical trials with DuoTrav ${ }^{\circledR}$ (Alcon, Fort Worth, USA) and Ganfort ${ }^{\circledR}$ (Allergan, Irvine, USA), TAF/TIM caused less superficial ocular side effects and less conjunctival hyperemia. Plausible explanations for the differences in side effects between the fixed-combination products are discussed.

Keywords: DuoTrav ${ }^{\circledR}$; Fixed-dose combination; Ganfort $^{\circledR}$; Hyperemia; Intraocular pressure; Ophthalmology; Preservative free; Side effects; Tafluprost; Timolol; Xalacom ${ }^{\circledR}$

\section{INTRODUCTION}

A new preservative-free fixed-dose combination product consisting of $0.0015 \%$ tafluprost and 0.5\% timolol [TAF/TIM, Santen Oy, Tampere, Finland; Marketing authorization pending at time of manuscript preparation. For the other reviewed products proprietary names Xalacom ${ }^{\circledR}$ 
(Pfizer, New York, USA), DuoTrav ${ }^{\circledR}$ (Alcon, Fort Worth, USA), and Ganfort ${ }^{\circledR}$ (Allergan, Irvine, USA) are used, to distinguish from studies with possible generic preparations] has recently been developed for the treatment of open-angle glaucoma and ocular hypertension. The purpose of the present paper is to review TAF/ TIM along with the other prostaglandintimolol fixed-combination products on the market-Xalacom ${ }^{\circledR}(0.005 \%$ latanoprost and $0.5 \%$ timolol), DuoTrav ${ }^{\circledR}(0.004 \%$ travoprost and $0.5 \%$ timolol), and Ganfort ${ }^{\circledR} \quad(0.03 \%$ bimatoprost and $0.5 \%$ timolol)—based on the double-masked, controlled phase III clinical trials that have been published. The intraocular pressure (IOP)-reducing effects of the products are discussed and the side effect profiles are summed up based on the receptor pharmacology of the compounds and the presence or absence of preservatives.

The pharmacological profiles of latanoprost, travoprost, and bimatoprost have been presented and discussed in detail [1-3]. All these compounds are prodrugs of synthetic analogs of prostaglandin $\mathrm{F}_{2 \alpha}\left(\mathrm{PGF}_{2 \alpha}\right)$ and act on prostaglandin $\mathrm{F}(\mathrm{FP})$ prostanoid receptors. Bimatoprost, an ethylamide of 17-phenyl, $18,19,20$-trinor-PGF ${ }_{2 \alpha}$ can be regarded both as a prostaglandin prodrug and a prostamide [4-6]. Specific prostamide receptors, like the prostanoid receptors, have not been identified so far. However, heterodimerization of prostanoid receptors may act as binding/ signaling site for the prostamide [7].

Similar to the other prostaglandin analogs, tafluprost

(15-difluoro-16-phenoxy$17,18,19,20$-tetranor-PGF $2 \alpha$-isopropyl ester) is a prodrug. The free acid of tafluprost is an FP prostanoid receptor agonist with some spillover of activity on the prostaglandin $\mathrm{E}$ receptor 3 $\left(\mathrm{EP}_{3}\right)[8,9]$. Tafluprost-free acid appears to be the most potent of the prostaglandin analogs used for glaucoma treatment with a half maximal effective concentration $\left(\mathrm{EC}_{50}\right)$ value at the FP receptor of around $5 \times 10^{-10} \mathrm{~mol} / \mathrm{L}$. Tafluprost is a unique prostaglandin analog in the sense that the hydrogen and hydroxyl group at carbon 15 have been replaced by two fluorine atoms; this affects both the pharmacology and metabolism of the drug.

Timolol is a well-known unselective betaadrenergic antagonist that has been widely used for glaucoma treatment since the late 1970s. Many review articles have been published on the pharmacology and use of timolol in glaucoma treatment [10-12]. The first fixedcombination product of a prostaglandin with timolol was Xalacom ${ }^{\circledR}$, followed by DuoTrav ${ }^{\circledR}$ and Ganfort ${ }^{\circledR}$.

Already the first phase III clinical trials with Xalacom ${ }^{\circledR}$ showed that the additional effect of combining timolol with latanoprost compared to latanoprost or timolol alone was somewhat smaller than expected $[13,14]$. The same finding has been reported for all the prostaglandin-timolol fixed-combination products: DuoTrav ${ }^{\circledR}[15,16]$, Ganfort $^{\circledR}$ [17-19], and TAF/TIM [20]. Clearly, from a dose regimen point of view, the two drugs are difficult to combine into one and get a full additive effect. The prostaglandin/prostamide should optimally be administered once daily in the evening to get the peak effect during the morning hours when IOP is physiologically at its highest. Timolol, in turn, is usually administered twice daily. To a certain extent, the worse-than-expected efficacy of the fixed-combination products is due to the design of previous regulatory trials (morningdosed combination products were compared to evening-dosed prostaglandins, therefore, daytime measurements tended to underestimate the relative efficacy of combination products). Additional issues included the selection of suboptimal baseline 
pressure and the inclusion of patients who were well controlled on monotherapy or were timolol non-responders. Despite these challenges, additional IOP reduction is achieved with the combination products in comparison with the monotherapies. This could be particularly relevant for patients who suffer from high IOP. Treatment compliance is another beneficial aspect that can be anticipated to improve with the combination products administered once daily [21-24].

\section{METHODS}

The present paper is based on a review of the double-masked, controlled clinical trials with the four fixed-combination products that have published results in the ophthalmic literature: Xalacom $^{\circledR}$, DuoTrav ${ }^{\circledR}$, Ganfort ${ }^{\circledR}$, and TAF/TIM. The paper focuses entirely on the data reported with these combination products; study results obtained with the control substances have not been included. Specifically, interest was laid in determining the relationship between the baseline IOP and treatment-induced change in IOP. A PubMed search with keywords latanoprost, travoprost, or bimatoprost, combined with timolol fixed was carried out in early July 2014. A prerequisite for accepting a trial in our paper was the washout of previous IOP-reducing medication before the initiation of the treatment with the combination product. Thus, studies with crossover design or an active run-in phase before the treatment period were not included in the evaluation of the IOP-reducing effect. For example, some Xalacom $^{\circledR}$ studies $[13,14,25,26]$ fell into this category. In addition, studies with an exclusively Asian population were excluded [27]. Open-label or investigator-masked (single-masked) studies were not included due to the potential problem with bias. Other factors that needed consideration were the length of the treatment that varied among the studies and the type of endpoint. Owing to these, we focused on the analysis of mean IOP change at 3 months; this standardized the follow-up period to that applied in majority of the studies and provided a distinct study endpoint (Table $1 ; 10$ studies). The robustness of these primary results was then assessed including all selected studies in the analysis (Table $1 ; 16$ studies). It should be noted that the reductions of IOP (in $\mathrm{mmHg}$ ) were generally calculated from the mean values given in the publications, because the underlying raw data were available only for the two TAF/TIM studies. Thus, these figures represent fair approximations rather than exact values. Statistical analyses were conducted using SAS ${ }^{\circledR}$ System for Windows, version 9.3 (SAS Institute Inc., Cary, NC, USA).

Regarding safety, the emphasis was on investigating hyperemia and ocular irritation (or discomfort), which are the most frequent side effects with prostaglandins [28]. Increased iris pigmentation, hyperpigmentation of the skin, and growth of eyelashes have not been dealt with as the duration of the treatment was only 3 months or less in most of the studies (Table $2 ; 11$ out of 16 studies). Incidences of the side effects-expressed as percentages-were obtained by summing up the counts of the individual side effects within a specific category. For example, subjective symptoms of various forms of discomfort (burning, stinging, itching, pruritus, foreign body sensation, ocular pain, ocular discomfort, and dry eye sensation) were lumped together and described as ocular "irritation". In most papers, drug-related adverse events have been incorporated into tables or are mentioned in the text only if their occurrence exceeded $2 \%$. Thus, drug- 
Table 1 Different fixed-combination prostaglandin-timolol drugs in double-blind, controlled, phase III clinical trials based on the literature (excluding studies using crossover design, run-in drug, or direct switch from previous medication)

\begin{tabular}{|c|c|c|c|c|c|}
\hline Drug & $\begin{array}{l}\text { Number of } \\
\text { patients }\end{array}$ & Endpoint & Dataset & $\begin{array}{l}\text { Dosing time of } \\
\text { fixed combination }\end{array}$ & References \\
\hline Xalacom $^{\circledR}$ & 255 & 3 months & ITT & Evening & Diestelhorst and Larsson [39] \\
\hline Xalacom ${ }^{\circledR}$ & 164 & 12 months $^{\mathrm{a}}$ & PP & Morning & Topouzis et al. [40] \\
\hline Xalacom $^{\circledR}$ & 129 & 3 months & ITT & Evening & Higginbotham et al. [32] \\
\hline Xalacom $^{\circledR}$ & 170 & 3 months & ITT & Evening & Palmberg et al. [41] \\
\hline DuoTrav $^{\circledR}$ & 151 & 3 months & $\mathrm{PP}$ & Morning & Hughes et al. [29] \\
\hline DuoTrav $^{\circledR}$ & 155 & 3 months & PP & Morning & Schuman et al. [15] \\
\hline DuoTrav $^{\circledR}$ & 82 & 3 months & ITT & Morning & Barnebey et al. [16] \\
\hline DuoTrav $^{\circledR}$ & 168 & 12 months $^{a}$ & $\mathrm{PP}$ & Morning & Topouzis et al. [40] \\
\hline DuoTrav $^{\circledR}$ & 154 & 6 weeks $^{a}$ & ITT & Morning & Teus et al. [42] \\
\hline DuoTrav $^{\circledR}$ & 372 & 6 weeks & $\mathrm{PP}$ & Morning & Kitazawa et al. [43] \\
\hline Ganfort $^{\circledR}$ & 178 & 3 weeks & ITT & Morning & Hommer et al. [17] \\
\hline Ganfort $^{\circledR}$ & 533 & 3 months & ITT & Morning & Brandt et al. $[18]$ \\
\hline Ganfort $^{\circledR}$ & $533^{\mathrm{b}}$ & 12 months ${ }^{b}$ & ITT & Morning & Lewis et al. [19] \\
\hline Ganfort $^{\circledR}$ & $516^{\mathrm{c}}$ & 3 months & PP & Morning & Goldberg et al. [31] \\
\hline TAF/TIM & 201 & 3 months & ITT & Morning & Holló et al. [30] \\
\hline TAF/TIM & 283 & 3 months & ITT & Morning & Pfeiffer et al. [20] \\
\hline
\end{tabular}

$I O P$ intraocular pressure, ITT intention-to-treat, $P P$ per-protocol, TAF/TIM fixed-dose combination of $0.0015 \%$ tafluprost and $0.5 \%$ timolol

a The endpoint calculated as a combined reduction in IOP over all time points during the 12-month or 6-week period

b Continuation of study by Brandt et al. [18] (same patients)

${ }^{c}$ In PP: 256 patients treated with preservative-free Ganfort ${ }^{\circledR}$ and 260 patients with preserved Ganfort ${ }^{\circledR}$. By chance same baseline IOP

related adverse events that occurred at a lower incidence than $2 \%$ were generally not included. Again, it is stressed that our figures represent only approximations, since we had limited access to the raw data. Also, the evaluation of hyperemia has varied among the studies, but this shortcoming is at least partly compensated by the fact that all studies were double masked and had a control substance.

The analysis in this article is based on previously conducted studies and does not involve any new studies of human or animal subjects performed by any of the authors.

\section{RESULTS}

\section{Intraocular Pressure}

The primary results-that is, mean IOP changes at 3 months versus mean baseline IOP-for the fixed prostaglandin-timolol combination products are presented as a scatter plot in 
Table 2 Incidence of conjunctival/ocular hyperemia and ocular irritation (burning, stinging, itching, foreign body sensation, pain, pruritus, ocular discomfort, and dry eye sensation) in percentage of patients in safety analyses

\begin{tabular}{|c|c|c|c|c|c|c|}
\hline Drug & $\begin{array}{l}\text { Number of } \\
\text { patients in } \\
\text { safety analysis }\end{array}$ & $\begin{array}{l}\text { Duration of } \\
\text { treatment }\end{array}$ & Preservative & $\begin{array}{l}\text { Hyperemia } \\
(\%)\end{array}$ & $\begin{array}{l}\text { Irritation } \\
(\%)\end{array}$ & References \\
\hline Xalacom $^{\circledR}$ & 262 & 3 months & $\mathrm{BAC}(0.02 \%)$ & 3.1 & 2.3 & $\begin{array}{l}\text { Diestelhorst and } \\
\text { Larsson [39] }\end{array}$ \\
\hline Xalacom ${ }^{\circledR}$ & 200 & 12 months & $\mathrm{BAC}(0.02 \%)$ & 2.5 & 9.0 & Topouzis et al. [40] \\
\hline Xalacom $^{\circledR}$ & 129 & 3 months & $\mathrm{BAC}(0.02 \%)$ & 8.5 & 8.5 & Higginbotham et al. [32] \\
\hline Xalacom ${ }^{\circledR}$ & 170 & 3 months & $\mathrm{BAC}(0.02 \%)$ & 1.8 & $\mathrm{~N} / \mathrm{a}^{\mathrm{c}}$ & Palmberg et al. [41] \\
\hline DuoTrav ${ }^{\circledR}$ & 161 & 3 months & $\mathrm{BAC}(0.015 \%)$ & 12.4 & 11.8 & Hughes et al. [29] \\
\hline DuoTrav $^{\circledR}$ & 161 & 3 months & $\mathrm{BAC}(0.015 \%)$ & 14.3 & 23.6 & Schuman et al. [15] \\
\hline DuoTrav $^{\circledR}$ & 85 & 3 months & BAC $(0.015 \%)$ & 14.1 & 14.1 & Barneyby et al. [16] \\
\hline DuoTrav ${ }^{\circledR}$ & 207 & 12 months & $\mathrm{BAC}(0.015 \%)$ & 15.0 & 14.4 & Topouzis et al. [40] \\
\hline DuoTrav ${ }^{\circledR}$ & 157 & 6 weeks & $\mathrm{BAC}(0.015 \%)$ & 10.8 & 11.5 & Teus et al. [42] \\
\hline \multirow[t]{2}{*}{$\operatorname{DuoTrav}^{\circledR}$} & 193 & 6 weeks & $\mathrm{BAC}(0.015 \%)$ & 13.0 & 16.6 & Kitasawa et al. [43] \\
\hline & 195 & 6 weeks & Polyquad $^{\mathrm{a}}$ & 11.8 & 12.8 & \\
\hline Ganfort $^{\circledR}$ & 176 & 3 weeks & BAC $(0.005 \%)$ & 19.3 & 18.8 & Hommer et al. [17] \\
\hline Ganfort $^{\circledR}$ & 533 & 3 months & $\mathrm{BAC}(0.005 \%)$ & 22.7 & 20.5 & Brandt et al. [18] \\
\hline Ganfort $^{\circledR}$ & $533^{\mathrm{b}}$ & 12 months & $\mathrm{BAC}(0.005 \%)$ & 25.7 & 23.8 & Lewis et al. [19] \\
\hline \multirow[t]{2}{*}{ Ganfort $^{\circledR}$} & 282 & 3 months & $\mathrm{BAC}(0.005 \%)$ & 19.5 & 8.5 & Goldberg et al. [31] \\
\hline & 278 & 3 months & Preservative free & 21.2 & 14.4 & \\
\hline TAF/TIM & 201 & 6 months & Preservative free & 8.0 & 7.0 & Holló et al. [30] \\
\hline TAF/TIM & 283 & 6 months & Preservative free & 6.4 & 12.7 & Pfeiffer et al. [20] \\
\hline
\end{tabular}

If information available in publication, percentages calculated from number of patients with individual adverse events, otherwise by summing incidences

$B A C$ benzalkonium chloride, IOP intraocular pressure, ITT intention-to-treat, PP per-protocol, TAF/TIM fixed-dose combination of $0.0015 \%$ tafluprost and $0.5 \%$ timolol

a Polyquad used at $0.001 \%$

b Continuation of study by Brandt et al. [18] (same patients)

c Not possible to assess due to incomplete data in publication

Fig. 1 (10 studies). The lowest and highest mean baseline IOPs were seen in studies conducted with DuoTrav ${ }^{\circledR}$ : Hughes et al. [29] and Schuman et al. [15] reported a mean of around $24 \mathrm{mmHg}$ and Barnebey et al. [16] a mean of around $29 \mathrm{mmHg}$. Interestingly, the reduction in mean IOP was smallest with the first two studies (around $8 \mathrm{mmHg}$ ) and largest with the third study (around $10 \mathrm{mmHg}$ ). In other words, the mean IOP at baseline seemed to predominantly explain the magnitude of IOP reduction. In essence, our regression 


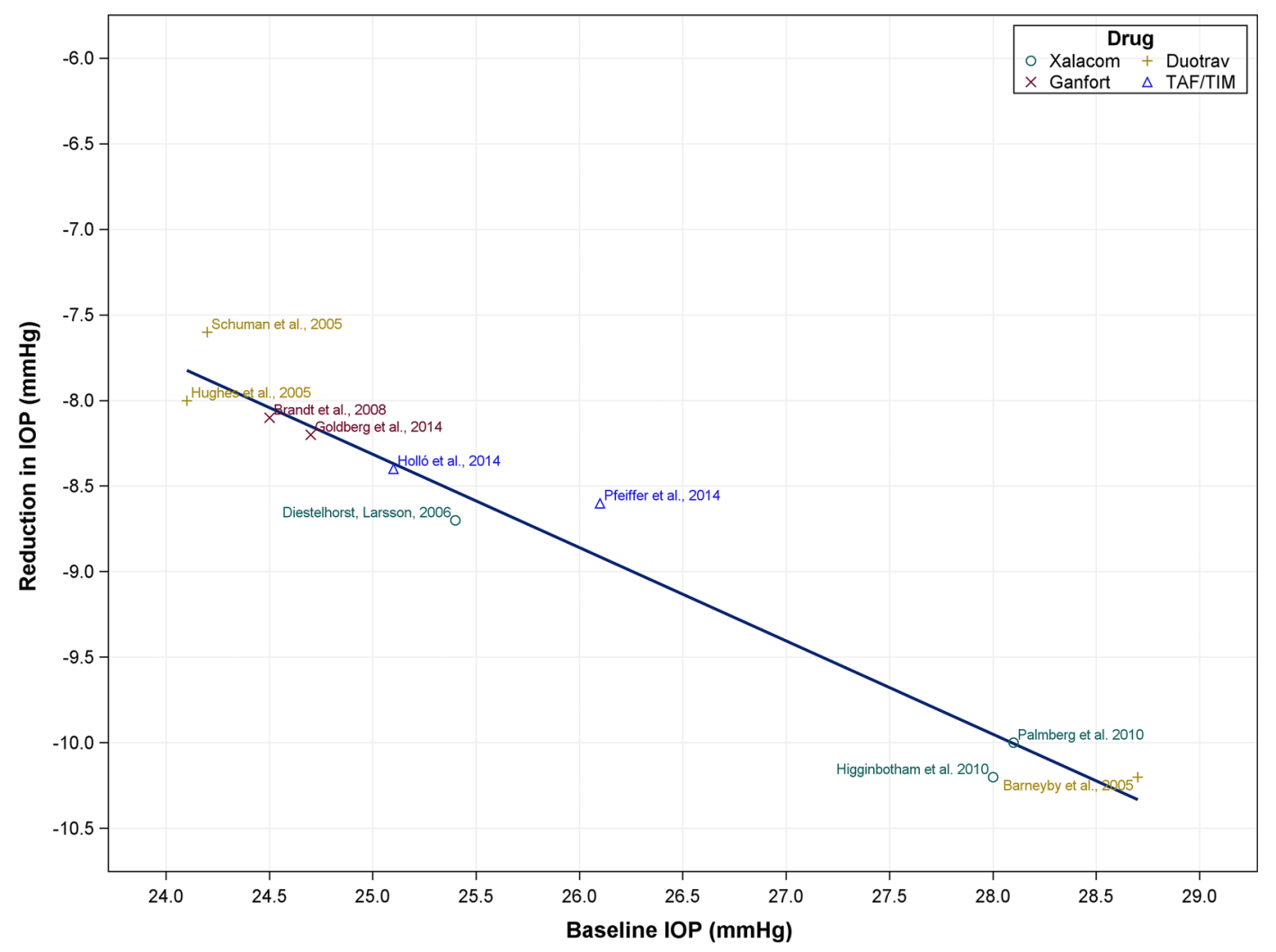

Fig. 1 A scatter plot of the baseline mean IOP versus reduction in mean IOP at 3 months based on the results of double-masked, randomized studies of the fixed-combination products. Results are shown from studies in which washout period from prior glaucoma medication was applied to have corresponding untreated baseline IOP values and the mean

analysis confirmed this finding: there was an outstanding linear relationship between the mean baseline IOP and the treatment-induced mean reduction in IOP across the 10 studies with fixed-combination products. On the grounds of the adjusted coefficient of determination from the regression, $96 \%$ of the variation in the mean IOP reduction was solely explained by the variation in the mean baseline IOP. The regression-based estimates of IOP reduction were also well in line with the published ones: for example, a mean reduction of $8 \mathrm{mmHg}(32 \%)$ was predicted for a mean baseline IOP of $24 \mathrm{mmHg}$ and a mean reduction of $10 \mathrm{mmHg}(36 \%)$ for a mean reduction at 3 months was available. Regression equation: reduction in IOP $=5.306-0.545 \times($ Baseline IOP $)$. Slope $P$ value $<0.0001$, adjusted $R^{2}$ 0.957. IOP intraocular pressure, TAF/TIM fixed-dose combination of $0.0015 \%$ tafluprost and $0.5 \%$ timolol

baseline IOP of $29 \mathrm{mmHg}$. Naturally, heterogeneity was increased, when the studies with variable lengths and endpoints were included in the analyses (16 studies); nevertheless, this supplemental regression analysis provided sound evidence on the robustness of our primary results (Fig. 2).

A combined analysis of the two phase III clinical trials with TAF/TIM [20, 30] demonstrated a similar linear relationship between the baseline IOP and magnitude of IOP reduction (Fig. 3). It is worth noticing that TAF/TIM had excellent IOP-reducing efficacy beyond the above-mentioned range of baseline IOPs: mean IOP reductions of up to $40 \%$ 


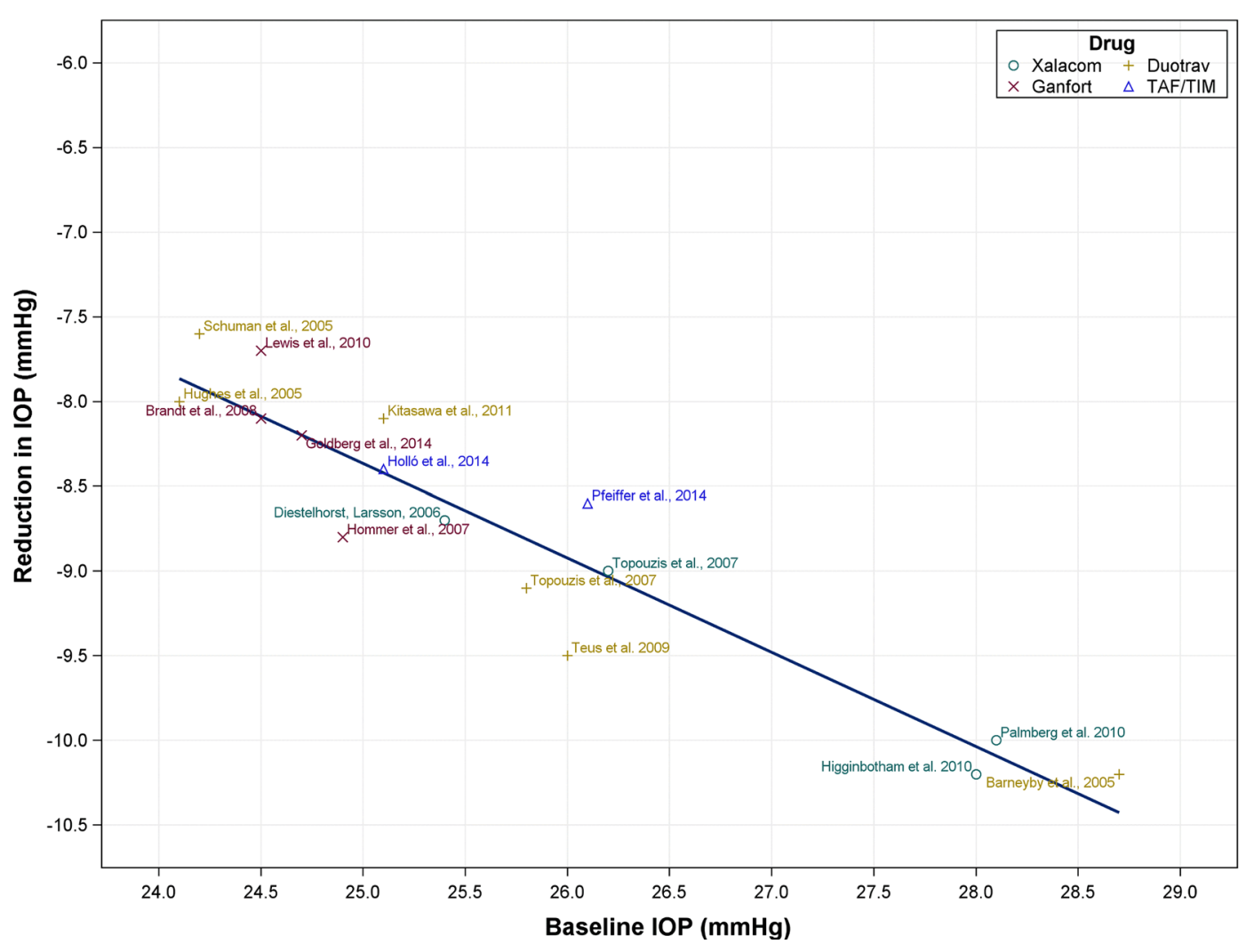

Fig. 2 A scatter plot of the mean baseline IOP versus reduction in mean IOP based on the results of doublemasked, randomized studies of the fixed-combination products. Results are shown from studies in which washout period from prior glaucoma medication was applied to have corresponding untreated baseline IOP. In addition to

$(>13 \mathrm{mmHg}$ ) were registered if the mean baseline IOP was $31 \mathrm{mmHg}$ or higher.

\section{Side Effects}

The most pronounced differences among the combination products appear to be in the incidence of side effects and tolerability (Table 2). Conjunctival/ocular hyperemia occurred at the highest occurrence with Ganfort $^{\circledR}$ : around $20-25 \%$ of the patients consistently exhibited hyperemia. Surprisingly, there was no difference in this respect between the preserved [benzalkonium chloride (BAC)] and preservative-free formulations indicating studies in Fig. 1, studies with results from endpoints other than 3 months are also included. Regression equation: reduction in IOP $=5.559-0.557 \times($ Baseline IOP). Slope $P$ value $<0.0001$, adjusted $R^{2} \quad 0.874$. IOP intraocular pressure, TAF/TIM fixed-dose combination of $0.0015 \%$ tafluprost and $0.5 \%$ timolol

that the hyperemia is likely caused by an inherent property of bimatoprost itself. Corresponding figures for the other three products were: around $13 \% \quad$ DuoTrav $^{\circledR}$ preserved with BAC/polyquad), 7\% (TAF/TIM), and $4 \%$ (Xalacom ${ }^{\circledR}$ preserved with $\left.\mathrm{BAC}\right)$. It is worth noticing that the results for the different products were consistent across the individual trials, for example, in the six DuoTrav ${ }^{\circledR}$ trials hyperemia occurred in 11-15\% of the patients.

Ocular irritation was also most common in patients treated with Ganfort ${ }^{\circledR}$ and occurred in most studies at an occurrence of 9-24\%. The corresponding figures for DuoTrav ${ }^{\circledR}$ were around $12-24 \%$ and for Xalacom ${ }^{\circledR}$ around 
TAFITIM IOP Change from Baseline at Month 3 (201050\&201051 combined)

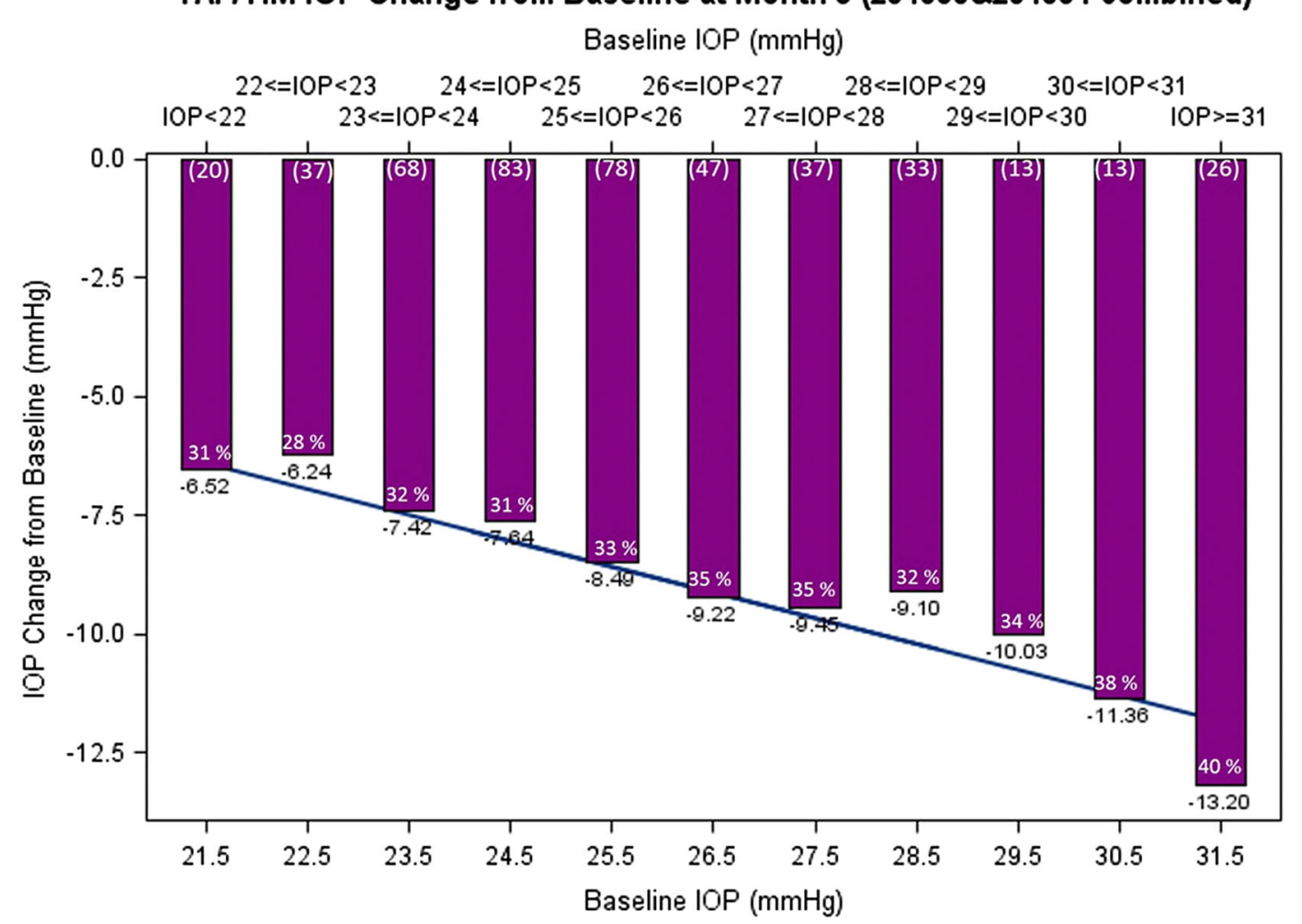

Fig. 3 IOP reduction at 3 months in patients treated with TAF/TIM (ITT dataset). The graph is based on a combined analysis of two phase III clinical trials (Holló et al. [30] and Pfeiffer et al. [20]) for which the patient population was stratified by daytime baseline IOP (mean of 3 or 4 measurements, $n$ for each category in parenthesis for every bar). It is evident that there is a direct relationship between the baseline IOP and the IOP reduction. In

2-9\%. Ocular irritation during TAF/TIM treatment occurred in about $7-13 \%$ of the patients. Furthermore, adverse events in the cornea occurred in most trials at low frequencies; at the most in 3-4\% of patients in Ganfort $^{\circledR}$ and Xalacom ${ }^{\circledR}$ trials $[18,19,31,32]$.

\section{DISCUSSION}

The double-masked, controlled phase III clinical trials with the fixed prostaglandin-timolol combination products-Xalacom ${ }^{\circledR}$, DuoTrav ${ }^{\circledR}$, patients with mean baseline IOP of at least $31 \mathrm{mmHg}$ the mean reductions in IOP of $40 \%(>13 \mathrm{mmHg})$ were achieved with TAF/TIM. A regression line from Fig. 1 was included to further depict that TAF/TIM is competitive in reducing IOP with regard to all other fixed prostaglandintimolol combination products. IOP intraocular pressure, ITT intention-to-treat, TAF/TIM fixed-dose combination of $0.0015 \%$ tafluprost and $0.5 \%$ timolol

Ganfort $^{\circledR}$, and TAF/TIM-were the basis of the current review. The mechanism of IOP reduction is similar for all of these products; the reduction of aqueous humor production induced by timolol, and the enhancement of aqueous humor outflow via FP prostanoid receptor activation induced by the prostaglandin component. Based on the results of our review, it is obvious that the capacity to reduce IOP in patients with open-angle glaucoma or ocular hypertension with the products is approximately $32-36 \%$ from the 
mean baseline pressures of around 24-29 mmHg. The regression analyses also suggest that the four fixed-combination products can be regarded as equally efficacious, as the study-wise variations in the magnitude of IOP reductions were explicitly explained by the corresponding variations in the baseline IOPs. Undoubtedly, our approach to concentrate on double-masked, controlled phase III trials with a parallel group design and proper washout period reduced bias, but at the same time it also diminished the spectrum of available studies and data.

In a combined analysis of the two TAF/TIM phase III studies [20, 30], an analogous linear relationship between the baseline IOP and level of IOP reduction was seen, and IOP decreases of up to $40 \%$ and beyond were achieved when the baseline IOP was $31 \mathrm{mmHg}$ or higher. Such pressure reductions would seem to be very beneficial in the treatment of glaucoma with high IOP. Moreover, the results of Pfeiffer et al. [20] suggest that the superiority of TAF/TIM over the underlying monotherapies- $0.0015 \%$ tafluprost once daily and $0.5 \%$ timolol twice daily_was more pronounced in patients with a high baseline IOP. Taken together, these results indicate that baseline IOP has a distinct role in the interpretation of study results and, clearly, needs to be taken into account when choosing the correct treatment option.

The most evident differences among the combination products appear to be in the incidence of side effects and tolerability; in general, TAF/TIM and Xalacom ${ }^{\circledR}$ seem to be associated with fewer side effects. The safety profile of timolol is well documented and does not differentiate the combination products [11, 24]. All prostaglandin analogs are rather selective FP prostanoid receptor agonists-also bimatoprost after amide hydrolysis. However, some subtle differences exist, which may explain the differences. Below, we will delve into these and also discuss the role of preservatives.

Xalacom $^{\circledR}$ contains a very high concentration of BAC (0.02\%) and yet causes conjunctival hyperemia on average in only about $3 \%$ of the patients (Table 2), while preservative-free Ganfort ${ }^{\circledR}$ was recently shown to cause hyperemia in about $21 \%$ of the patients and the BAC-preserved Ganfort ${ }^{\circledR}$ in about 20\% of the patients [31]. Therefore, it seems likely that hyperemia is caused mainly by the prostaglandin analog itself-as timolol is well known to induce no or minimal hyperemia (or irritation) in the eye, or may even help reducing hyperemia induced by the other component of the fixed combinations [24]. FP receptormediated vasodilation is complex, and may involve the release of secondary mediators [33]. The concentration of the prostaglandin/ prostamide component in DuoTrav ${ }^{\circledR}$, Ganfort $^{\circledR}$, and TAF/TIM is high in relation to the $\mathrm{EC}_{50}$ value of the drugs, which may result in overstimulation of the FP receptor on the surface structures of the eye and cause more frequent hyperemia compared to $\mathrm{Xalacom}^{\circledR}$, which contains a less potent FP receptor agonist latanoprost [1, 34]. TAF/TIM, on the other hand, stimulates $\mathrm{EP}_{3}$ receptors [8, 9], which can be expected to cause vasoconstriction [7] and thereby counteract part of the vasodilation caused by the FP receptor stimulation. This could explain why the hyperemia caused by TAF/TIM appears to be less frequent and less severe than that of Ganfort $^{\circledR}$ and DuoTrav ${ }^{\circledR}$.

Stimulation of the FP prostanoid receptor does not seem to be associated with nociception/irritation in the eye [1]. Therefore, it is likely that co-stimulation of some other receptor is of importance. Ganfort ${ }^{\circledR}$ caused most frequently ocular irritation (9-24\%) and, 
indeed, bimatoprost-free acid (17-phenyl$18,19,20$-trinor-PGF ${ }_{2 \alpha}$ ) has significant stimulatory effect on the $\mathrm{EP}_{1}$ prostanoid receptor, which seems to be associated with irritation in the eye $[1,34]$. The preservative (BAC in $\mathrm{Xalacom}^{\circledR}$ and $\mathrm{BAC} /$ polyquad in DuoTrav $\left.^{\circledR}\right)$ can also be a plausible explanation-or at least a contributing factor-for the irritation: DuoTrav ${ }^{\circledR}$ caused irritation in $12-24 \%$ of the patients and Xalacom $^{\circledR}$ in $2-9 \%$ of the patients, even though travoprost-free acid (15R-fluprostenol) is a more selective FP prostanoid receptor agonist than latanoprost. TAF/TIM, in turn, seemed to exert relatively little ocular irritation, which could be due to the fact that the eye drops are preservative free. On the other hand, taking into account the relatively short period of exposure, it is as likely that the improved tolerability profile of TAF/TIM is due to the active ingredient. Nevertheless, the absence of preservative will certainly improve the long-term tolerability of TAF/TIM.

Obviously, it is crucial to take into account the length of the treatment when trying to rationalize the reasons for the differences in the incidence of side effects among the four fixedcombination products (Table 2). The shortest of the trials has lasted only 3 weeks (with Ganfort ${ }^{\circledR}$ ) and the longest 12 months (with Xalacom $^{\circledR}$, DuoTrav ${ }^{\circledR}$, and Ganfort ${ }^{\circledR}$ ). The importance of the length of the treatment is illustrated by the studies of Brandt et al. [18] and Lewis et al. [19] in which the same cohort of patients continued treatment with Ganfort ${ }^{\circledR}$ from 3 to 12 months: A moderate increase was seen both in hyperemia (from $22.7 \%$ at 3 months to $25.7 \%$ at 12 months) and irritation (from $20.5 \%$ at 3 months to $23.8 \%$ at 12 months). Accordingly, a notable decline in the IOP-reducing efficacy was seen from 3 to 12 months (Fig. 2). Hence, to avoid the imminent bias, our primary regression analysis was conducted on 3-month results. Moreover, most of the trials included in the analysis of safety had a duration of treatment up to 3-6 months (Table $2 ; 10$ out of 16 studies); therefore, the error imposed by the variation in treatment length should not be significant for the overall interpretation of the side effect results either.

It should also be noted that subsequent to the phase III studies a number of complete $24-\mathrm{h}$ crossover comparison studies have been published with Xalacom $^{\circledR}$, DuoTrav ${ }^{\circledR}$, and Ganfort $^{\circledR}$ (e.g., [35-38]). These studies could not be included in the current analysis; but their clinical relevance is emphasized, as they highlight the true overall efficacy of the products and have revealed a convincing separation between the products and prostaglandin constituents. Such studies have not yet been conducted with TAF/TIM combination, but could be of future research interest.

\section{CONCLUSION}

In conclusion, a review of the double-masked, controlled, phase III clinical trials with the fixed-combination products of prostaglandin and timolol revealed that the products yielded a similar reduction in IOP of approximately $32-36 \%$ from an untreated baseline IOP of around 24-29 mmHg. A further look on TAF/ TIM studies indicated that IOP reductions of up to $40 \%$ and beyond could be achieved for untreated baseline pressures of $31 \mathrm{mmHg}$ or higher. Least side effects occurred during treatment with TAF/TIM and Xalacom ${ }^{\circledR}$. Of these two, only TAF/TIM is preservative free. Although preservatives may induce ocular surface problems, preservative-free Ganfort ${ }^{\circledR}$ 
did not cause less hyperemia or irritation than the preserved preparation indicating that these side effects are associated with an inherent property of bimatoprost.

\section{ACKNOWLEDGMENTS}

This article and associated article processing charges were sponsored by Santen Oy, Tampere, Finland. The sponsor participated in the preparation, review, and approval of the manuscript. Editorial assistance in the preparation of this manuscript was provided by Johan Stjernschantz, MD, PhD, Synphora Ab, Sweden. Support for this assistance was funded by Santen Oy. All named authors meet the ICMJE criteria for authorship for this manuscript, take responsibility for the integrity of the work as a whole, and have given final approval to the version to be published.

\section{Conflict of interest. Gábor Holló has} received research grants and speaker honorariums from Santen Oy. Jouni Vuorinen represents Oy 4Pharma Ltd, a statistical company which has participated in the TAF/ TIM and tafluprost studies sponsored by Santen Oy. Juhani Tuominen has received grants for statistical advice from Santen Oy. Teppo Huttunen represents Oy 4Pharma Ltd, a statistical company which has participated in the TAF/TIM and tafluprost studies sponsored by Santen Oy. Auli Ropo is an employee of Santen Oy. Norbert Pfeiffer has received research grants and speaker honorariums from Santen Oy and a research grant from the Sir Emeka Offor Foundation.

Compliance with ethics guidelines. The analysis in this article is based on previously conducted studies, and does not involve any new studies of human or animal subjects performed by any of the authors.

Open Access. This article is distributed under the terms of the Creative Commons Attribution Noncommercial License which permits any noncommercial use, distribution, and reproduction in any medium, provided the original author(s) and the source are credited.

\section{REFERENCES}

1. Stjernschantz J. From $\mathrm{PGF}_{2 \alpha}$-isopropyl ester to latanoprost: a review of the development of Xalatan. Investig Ophthalmol Vis Sci. 2001;42:1134-45.

2. Hellberg MR, McLaughlin MA, Sharif NA, et al. Identification and characterization of the ocular hypotensive efficacy of travoprost, a potent and selective FP prostaglandin receptor agonist, and AL6598, a DP prostaglandin receptor agonist. Surv Ophthalmol. 2002;47(Suppl 1):S13-33.

3. Woodward DF, Krauss AH, Chen J, et al. The pharmacology of bimatoprost (Lumigan). Surv Ophthalmol. 2001;45(Suppl 4):S337-45.

4. Maxey KM, Johnson JL, LaBrecque J. The hydrolysis of bimatoprost in corneal tissue generates a potent prostanoid FP receptor agonist. Surv Ophthalmol. 2002;47(Suppl 1):S34-40.

5. Davies SS, Ju WK, Neufeld AH, Abran D, Chemtob S, Roberts LJ 2nd. Hydrolysis of bimatoprost (Lumigan) to its free acid by ocular tissue in vitro. J Ocul Pharmacol Ther. 2003;19:45-54.

6. Camras CB, Toris CB, Sjöquist B, et al. Detection of the free acid of bimatoprost in aqueous humor samples from human eyes treated with bimatoprost before cataract surgery. Ophthalmology. 2004;111:2193-8.

7. Woodward DF, Jones RL, Narumiya S. International union of basic and clinical pharmacology. LXXXIII: classification of prostanoid receptors, updating 15 years of progress. Pharmacol Rev. 2011;63:471-538.

8. Takagi Y, Nakajima $\mathrm{T}$, Shimazaki $\mathrm{A}$, et al. Pharmacological characteristics of AFP-168 (tafluprost), a new prostanoid FP receptor agonist, 
as an ocular hypotensive drug. Exp Eye Res. 2004;78:767-76.

9. Ota T, Aihara M, Saeki T, Narumiya S, Araie M. The IOP-lowering effects and mechanism of action of tafluprost in prostanoid receptor-deficient mice. $\mathrm{Br}$ J Ophthalmol. 2007;91:673-6.

10. Zimmerman TJ, Kaufman HE. Timolol. A betaadrenergic blocking agent for the treatment of glaucoma. Arch Ophthalmol. 1977;95:601-4.

11. Zimmerman TJ, Kass MA, Yablonski ME, Becker B. Timolol maleate: efficacy and safety. Arch Ophthalmol. 1979;97:656-8.

12. Juzych MS, Zimmerman TJ. Beta blockers. In: Zimmerman TJ, Kooner KS, Sharil M, Fechtner RD, editors. Textbook of ocular pharmacology. Philadelphia: Lippincott-Raven Publishers; 1997. p. 261-275.

13. Pfeiffer N. A comparison of the fixed combination of latanoprost and timolol with its individual components. Graefe's Arch Clin Exp Ophthalmol. 2002;240:893-9.

14. Higginbotham EJ, Feldman R, Stiles M, Dubiner H, For the Fixed Combination Investigative Group. Latanoprost and timolol combination therapy vs monotherapy. One-year randomized trial. Arch Ophthalmol. 2002;120:915-22.

15. Schuman JS, Kats GJ, Lewis RA, et al. Efficacy and safety of a fixed combination of travoprost $0.004 \% /$ timolol $0.5 \%$ ophthalmic solution once daily for open-angle glaucoma or ocular hypertension. Am J Ophthalmol. 2005;140:242-50.

16. Barnebey HS, Orengo-Nania S, Flowers BE, et al. The safety and efficacy of travoprost $0.004 \% /$ timolol $0.5 \%$ fixed combination ophthalmic solution. Am J Ophthalmol. 2005;140:1-7.

17. Hommer A, Ganfort ${ }^{\circledR}$ Investigators Group I. A double-masked, randomized, parallel comparison of a fixed combination of bimatorpost $0.03 \% /$ timolol $0.5 \%$ with non-fixed combination use in patients with glaucoma or ocular hypertension. Eur J Ophthalmol. 2007;17:53-62.

18. Brandt JD, Cantor LB, Katz LJ, Batoosingh AL, Chou C, Bossowska I, For the Ganfort ${ }^{\circledR}$ Investigators Group II. Bimatoprost/timolol fixed combination: a 3-month double-masked, randomized parallel comparison to its individual components in patients with glaucoma or ocular hypertension. J Glaucoma. 2008;17:211-6.

19. Lewis RA, Gross RL, Sall KN, Schiffman RM, Liu CC, Batoosingh $\mathrm{AL}$, For the Ganfort ${ }^{\circledR}$ Investigators Group II. The safety and efficacy of bimatoprost/ timolol fixed combination: a 1-year double-masked, randomized, parallel comparison to its individual components in patients with glaucoma or ocular hypertension. J Glaucoma. 2010;19:424-6.

20. Pfeiffer N, Traverso CE, Lorenz K, et al., For the Preservative-free Tafluprost Fixed Combination Study Group. A six month study comparing efficacy, safety, and tolerability of the preservative-free fixed combination of tafluprost $0.0015 \%$ and timolol $0.5 \%$ versus each of its individual preservative-free components. Adv Ther 2014 (submitted).

21. Patel SC, Spaeth GL. Compliance in patients prescribed eye drops for glaucoma. Ophthalmic Surg. 1995;26:234-6.

22. Sleath B, Robin AL, Covert D, et al. Patient-reported behavior and problems in using glaucoma medications. Ophthalmology. 2006;113:431-6.

23. Robin AL, Novack GD, Covert DW, et al. Adherence in glaucoma: objective measurements of once-daily and adjunctive medication use. Am J Ophthalmol. 2007;144:533-40.

24. Holló G, Topouzis F, Fechtner RD. Fixedcombination intraocular pressure-lowering therapy for glaucoma and ocular hypertension: advantages in clinical practice. Expert Opin Pharmacother. 2014;15:1737-47.

25. Olander $\mathrm{K}$, Zimmerman TJ, Downes $\mathrm{N}$, Schoenfelder J, For the Xalacom ${ }^{\circledR} /$ Latanoprost Study Group. Switching from latanoprost to the fixed combination latanoprost-timolol: a 21-day, randomized, double-masked, active-control study in patients with glaucoma and ocular hypertension. Clin Ther. 2004;26:1619-29.

26. Franks WA, Renard JP, Cunliffe IA, Rojanapongpun P. A 6-week double-masked, parallel-group study of the efficacy and safety of travoprost $0.004 \%$ compared with latanoprost $0.005 \% /$ timolol $0.5 \%$ in patients with primary open-angle glaucoma or ocular hypertension. Clin Ther. 2006;28:332-9.

27. Zhihong L, Mingchang Z, Yizhen H, et al. Safety and efficacy of bimatoprost/timolol fixed combination in Chinese patients with open-angle glaucoma or ocular hypertension. Chin Med J. 2014;127:905-10.

28. Holló G. The side effects of the prostaglandin analogues. Expert Opin Drug Saf. 2007;6:45-52.

29. Hughes BA, Bacharach J, Craven ER, et al. A threemonth, multicenter, double-masked study of the safety and efficacy of travoprost $0.004 \% /$ timolol $0.5 \%$ ophthalmic solution compared to travoprost $0.004 \%$ ophthalmic solution and timolol $0.5 \%$ 
dosed concomitantly in subjects with open angle glaucoma or ocular hypertension. J Glaucoma. 2005;14:392-9.

30. Holló G, Hommer A, Antón López A, Ropo A. Efficacy, safety and tolerability of preservative-free fixed combination of tafluprost $0.0015 \% /$ timolol $0.5 \%$ versus concomitant use of the ingredients. J Ocul Pharmacol Ther. 2014;30:468-75.

31. Goldberg I, Gil Pina R, Lanzagorta-Aresti A, Schiffman RM, Liu C, Bejanian M. Bimatoprost $0.03 \% /$ timolol $0.5 \%$ preservative-free ophthalmic solution versus bimatoprost $0.03 \%$ /timolol $0.5 \%$ $\left(\right.$ Ganfort $\left.^{\circledR}\right)$ for glaucoma or ocular hypertension: a 12-week randomized controlled trial. $\mathrm{Br} \mathrm{J}$ Ophthalmol. 2014;98:926-931.

32. Higginbotham EJ, Olander KW, Kim EE, Grunden JW, Kwok KK, Tressler CS, United States FixedCombination Study Group. Fixed combination of latanoprost and timolol vs individual components for primary open-angle glaucoma or ocular hypertension: a randomized, double-masked study. Arch Ophthalmol. 2010;128:165-72.

33. Astin M. A study on the vascular effects of prostaglandin $\mathrm{F}_{2 \alpha}$ and latanoprost in the eye with special reference to surface hyperemia after topical administration. Compr Summ Uppsala Univ dissertations Faculty of Medicine 1998. p.179.

34. Sharif NA, Kelly CR, Crider JY, Williams GW, Xu SX. Ocular hypotensive FP prostaglandin (PG) analogs: PG receptor subtype binding affinities and selectivities, and agonist potencies at FP and other PG receptors in cultured cells. J Ocul Pharmacol Ther. 2003;19:501-15.

35. Konstas AG, Voudouragkaki IC, Boboridis KG, et al. 24-hour efficacy of travoprost/timolol BAK-free versus latanoprost/timolol fixed combinations in patients insufficiently controlled with latanoprost. Adv Ther. 2014;31:592-603.

36. Konstas AG, Mikropoulos DG, Embesliis TA, et al. 24-h Intraocular pressure control with eveningdosed travoprost/timolol, compared with latanoprost/timolol fixed combinations in exfoliative glaucoma. Eye (Lond). 2010;24:1606-13.
37. Konstas AG, Tsironi $\mathrm{S}$, Vakalis $\mathrm{AN}$, et al. Intraocular pressure control over 24 hours using travoprost and timolol fixed combination administered in the morning or evening in primary open-angle and exfoliative glaucoma. Acta Ophthalmol. 2009;87:71-6.

38. Konstas AG, Holló G, Mikropoulos D, et al. Twentyfour-hour intraocular pressure control with bimatoprost and the bimatoprost/timolol fixed combination administered in the morning, or evening in exfoliative glaucoma. Br J Ophthalmol. 2010;94:209-13.

39. Diestelhorst M, Larsson L-I, for the EuropeanCanadian Latanoprost Fixed Combination Study Group. A 12-week, randomized, double-masked, multicenter study of the fixed combination of latanoprost and timolol in the evening versus the individual components. Ophthalmology. 2006;113:70-6.

40. Topouzis F, Melamed S, Danesh-Meyer H, et al. A 1-year study to compare the efficacy and safety of once-daily travoprost $0.004 \% /$ timolol $0.5 \%$ to once-daily latanoprost $0.005 \% /$ timolol $0.5 \%$ in patients with open-angle glaucoma or ocular hypertension. Eur J Ophthalmol. 2007;17:183-90.

41. Palmberg P, Kim EE, Kwok KK, Tressler CS, Canada and United States Fixed Combination Latanoprost/ Timolol Study Group. A 12-week, randomized, double-masked study of fixed combination latanoprost/timolol versus latanoprost or timolol monotherapy. Eur J Ophthalmol. 2010;20:708-18.

42. Teus MA, Miglior S, Laganovska G, et al. Efficacy and safety of travoprost/timolol vs dorzolamide/ timolol in patients with open-angle glaucoma or ocular hypertension. Clin Ophthalmol. 2009;3:629-36.

43. Kitazawa Y, Smith P, Sasaki N, Kotake S, Bae K, Iwamoto Y. Travoprost $0.004 \%$ /timolol $0.5 \%$-fixed combination with and without benzalkonium chloride: a prospective, randomized, doubledmasked comparison of safety and efficacy. Eye (Lond). 2011;25:1161-9. 